\title{
Enzyme supplementation of a poultry diet containing rye and wheat
}

\author{
BY D. PETTERSSON AND P. ÅMAN \\ Swedish University of Agricultural Sciences, Department of Animal Nutrition and Management, \\ Box 7024, S-750 07 Uppsala, Sweden
}

(Received 10 May 1988 - Accepted 26 January 1989)

\begin{abstract}
A total of 360 l-d-old broiler chickens were fed on a diet based on rye and wheat in equal proportions without or with supplementation of increasing levels $(0.11,0.22,0.44$ and $0.88 \mathrm{~g} / \mathrm{kg})$ of a technical enzyme preparation containing pentosanase and $\beta$-glucanase activities. In vitro investigations revealed that the enzyme preparation solubilized pentosans, increasing the relative viscosity of buffer extracts from enzyme-supplemented diets. Enzyme supplementation generally improved body-weight by approximately $27 \%$ at day 15 and $15 \%$ at day 27 , increased feed intake by 15 and $8 \%$ respectively, and improved feed conversion efficiency by 10 and $5 \%$ respectively. There was also a decreased occurrence of sticky droppings. Enzyme supplementation increased the digestibility of organic matter, crude protein (nitrogen $\times 6.25$ ) and starch measured in the last third of the small intestine, and of organic matter and crude fat measured in excreta. Solubilization of insoluble pentosans by the enzyme included led to negative digestibility values for soluble pentosans in the small intestine at the higher levels of supplementation. Most of the dietary fibre degradation observed occurred before the middle section of the small intestine, with some degradation of soluble fibre in the caeca and colon. The solubilization and disruption of feed endosperm cell walls by enzyme supplementation probably was primarily responsible for the observed improvements in digestibility and production results.
\end{abstract}

Enzyme supplementation: Digestibility : Pentosans: Chicken.

Dietary supplementation with microbial enzyme preparations capable of hydrolysing endosperm cell walls has increased performance of broiler chickens receiving cereal-based diets (Jensen et al. 1957; Fry et al. 1958; Burnett, 1966; White et al. 1981; Boros et al. 1985; Hesselman \& Åman, 1986; Scholtyssek \& Knorr, 1987; Pettersson \& Åman, 1988). Mixed-linked $\beta$-D-glucans and pentosans are the major constituents in endosperm cell walls, with the former predominating in barley and oats and the latter in rye, wheat and their hybrid crossing, triticale (Mares \& Stone, 1973; Fincher, 1975; Forrest \& Wainwright, 1977; Henry, 1985). The dietary administration of an enzyme preparation capable of partly hydrolysing pentosans and $\beta$-glucans has given significant improvements in performance of broiler chickens fed on the latter group of cereals (Pettersson \& Aman, 1988). The precise mechanisms involved in this improvement are not known, but the magnitude of the increase in productive value, particularly for the rye, shows that a greater fibre digestion per se is not the primary factor. In the present experiments this enzyme preparation was added in increasing amounts to a broiler chicken diet, based on rye and wheat in equal proportions, in order to study the effects on production and digestibilities of dietary constituents.

\section{MATERIALS AND METHODS}

\section{Diets}

A basal diet containing rye and wheat in equal proportions (Table 1) was milled to pass a $3.5 \mathrm{~mm}$ sieve and was given either untreated (level 0 ) or supplemented with $0 \cdot 11,0 \cdot 22,0 \cdot 44$ 
Table 1. Composition of the basal experimental diet $(\mathrm{g} / \mathrm{kg}$ fresh weight)

\begin{tabular}{|c|c|c|c|}
\hline Ingredient* & & Ingredient* & \\
\hline Rye & 305 & Limestone & 10 \\
\hline Wheat & 305 & Monocalcium phosphate & 10 \\
\hline Soya-bean meal & 246 & Vitamin and trace element premix $\dagger$ & 10 \\
\hline Meat and bone meal & 40 & Salt & 2 \\
\hline Fishmeal & 40 & Chromic oxide & 2 \\
\hline Fat & 30 & & \\
\hline
\end{tabular}

* Diets also contained Virginiamycin $(10 \mathrm{mg} / \mathrm{kg})$ and Monensin $(90 \mathrm{mg} / \mathrm{kg})$.

† The composition of vitamin and trace element premix $(\mathrm{mg} / \mathrm{kg})$ was: vitamin $A$ s00, vitamin $\mathrm{D}_{3} 6 \cdot 3$, vitamin E 2500, vitamin $B_{1} 100$, vitamin $B_{2} 500$, calcium pantothenate 1200 , folic acid 100 , pyridoxin 300 , niacin 2500 , choline chloride 30000 , vitamin $\mathrm{B}_{12} 1.5$, vitamin $\mathrm{K}_{3} 300, \mathrm{CoSO}_{4} 143, \mathrm{Na}_{2} \mathrm{SeO}_{3} 22, \mathrm{KI} 636$, $\mathrm{FeSO}_{4} 16000, \mathrm{ZnSO}_{4} 9000, \mathrm{ZnO} 4500, \mathrm{CuSO}_{4} 2000, \mathrm{MnSO}_{4} 25000$, antioxidant 5000 .

or $0.88 \mathrm{~g} / \mathrm{kg}$ feed of a technical pentosanase preparation (TSE-8) containing $16 \beta$-glucanase units/g (viscosimetric method) and 1300 xylanase units/g (reducing end group method) measured according to internal methods by the enzyme supplier (Grindsted Products A/S, Denmark). The diets were not pelleted and they all contained $2 \mathrm{~g}$ chromic oxide $/ \mathrm{kg}$ as a digestibility marker.

\section{Chemical analysis}

Before analysis all samples were ground to pass a $0.5 \mathrm{~mm}$ screen. The dry matter content was determined by oven-drying at $105^{\circ}$ for $16 \mathrm{~h}$, and chemical analyses, which were carried out in duplicate, are reported on a dry matter basis. Sugars (glucose, fructose, sucrose and fructans) were extracted with $0.05 \mathrm{M}$-sodium acetate buffer ( $\mathrm{pH} 5 \cdot 0$ ) at $65^{\circ}$ and determined enzymically (Larsson \& Bengtsson, 1983). Crude protein and ash were determined according to standard methods (Association of Official Analytical Chemists, 1984) and starch was determined by an enzymic method (Åman \& Hesselman, 1984). Crude fat was extracted with diethyl ether in a Tecator Soxtec System HT after acid hydrolysis (Anon., 1971). Dietary fibre was calculated as the sum of soluble and insoluble non-starch polysaccharide (NSP) residues and Klason lignin determined according to Theander \& Åman (1979), as modified by Theander \& Westerlund (1986). Gross energy determinations were performed on a Gallenkamp adiabatic calorimeter. For faecal digestibility calculations uric acid was determined according to Marquardt (1983) and $\mathrm{Cr}_{2} \mathrm{O}_{3}$ was measured by atomic absorption spectrophotometry (Williams et al. 1962). Relative viscosities of extracts were calculated as the descent time of extracts divided by the descent time of the extraction medium $(0 \cdot 1 \mathrm{M}$-sodium acetate buffer, $\mathrm{pH} 5 \cdot 0)$ measured on an Ostvald viscometer. Extractions were performed according to Pettersson et al. (1987).

For in vitro incubations duplicate $500 \mathrm{mg}$ samples of the basal diet containing $0,0.44$ or $4.4 \mathrm{~g}$ enzyme $/ \mathrm{kg}$ were incubated for 20,60 or $180 \mathrm{~min}$ at $37^{\circ}$ in $30-\mathrm{ml}$ screw-capped Pyrex tubes containing $15 \mathrm{ml}$ of the $0.1 \mathrm{M}$-sodium acetate buffer ( $\mathrm{pH} \mathrm{5.0)}$ ). After incubation samples were centrifuged for $5 \mathrm{~min}$ at $1500 \mathrm{~g}$ and washed twice with $5 \mathrm{ml}$ buffer by centrifugation. The combined supernatant fractions were made up to $25 \mathrm{ml}$ and a sample of $5 \mathrm{ml}$ was taken for analysis. Soluble dietary fibres were recovered by precipitation in aqueous ethanol $(800 \mathrm{ml} / 1)$ and determined as described previously.

\section{Chickens}

A total of 360 l-d-old unsexed broiler chickens (Hybro) were divided into twenty groups of eighteen chickens, with an average group weight of $729 \mathrm{~g}$, and a maximum difference in 
weight between groups of $4 \mathrm{~g}$. The groups were randomly allotted to five four-tier battery cages with raised wire floors in a windowless, light- and temperature-controlled room. The five experimental diets were assigned within-tiers across-batteries so that all five diets were represented on each tier. The birds had free access to water and feed throughout the entire experiment.

\section{Growth}

The chickens were weighed individually at 15 and $27 \mathrm{~d}$ of age. Group feed intakes (air dry weight, corrected for feed wastage) were registered on both weighing occasions and feed conversion efficiencies were calculated on a group weight basis.

\section{Digestibility}

The frequency of sticky droppings (i.e. wet excreta sticking to the down of the cloaca) was recorded on day 8 . Based on group-weighing at $19 \mathrm{~d}$ of age, four chickens from each group (sixteen from each treatment), weighing as closely as possible to the average group weight, were killed at day 20 by dislocation of the neck vertebra, and the gastrointestinal tract of each bird removed. The small intestine was measured and then divided into three equal parts of which the first part was discarded. The contents of the middle and last third of the small intestine (denoted middle section and last section respectively) were collected separately, pooled for each group, frozen $\left(-25^{\circ}\right)$ and freeze-dried. Digestibilities in the digesta samples were calculated relative to the $\mathrm{Cr}_{2} \mathrm{O}_{3}$ marker. Between 21 and $24 \mathrm{~d}$ of age a quantitative digestibility trial was conducted. Excreta were collected twice daily and kept frozen until mixed and freeze-dried. The apparent metabolizable energy content of the different diets (levels) was corrected to zero nitrogen retention as described by Hartfiel (1973). Faecal digestibilities of organic matter and crude protein $(\mathrm{N} \times 6.25)$ were calculated on the total collection according to Eriksson (1955) and Hartfiel (1973).

\section{Statistical analyses}

In the growth study statistical analyses of the variables measured at 15 and $27 \mathrm{~d}$ of age were performed using the general linear model (GLM) procedure (SAS Institute Inc., 1985), with block and the different levels of enzyme as the only main effects. In the digestibility experiment comparisons between levels of enzyme were done by contrasts provided by the GLM procedure (SAS Institute Inc., 1985).

\section{RESULTS}

\section{Diet}

Starch, crude protein, dietary fibre, ash and crude fat together constituted $91 \%$ of the dry matter content of the diet (Table 2). Pentosans, the sum of arabinose and xylose residues, were the dominating non-starch polysaccharides and constituted $39 \%$ of this fraction. The in vitro incubations revealed increased solubilization of pentosans in enzyme-supplemented diets (Table 3). However, with the highest enzyme level $(4.4 \mathrm{~g} / \mathrm{kg})$ the content of soluble pentosans decreased with incubation period showing that degradation of pentosans to lowmolecular-weight compounds, not analysed as dietary fibre, also occurred. Viscosity measurements showed an increased viscosity in buffer extracts from enzyme-treated diets (Fig. 1).

\section{Chickens}

Mortality was $1.7 \%$ in the experiment, excluding those chickens that were deliberately killed for the intestinal digestibility experiment, and was not significantly influenced by block or enzyme level. 
Table 2. Chemical composition of the basal diet ( $\mathrm{g} / \mathrm{kg}$ dry matter) and content of gross energy ( $M J / k g$ dry matter)

\begin{tabular}{lrll}
\hline \multicolumn{1}{c}{ Constituent } & & \multicolumn{2}{c}{ Constituent } \\
\hline Sugars & $56 \cdot 5$ & Insoluble non-starch polysaccharides & $89 \cdot 9$ \\
Starch & $403 \cdot 1$ & Arabinose residues & $16 \cdot 2$ \\
Crude protein (nitrogen $\times 6 \cdot 25)$ & $246 \cdot 6$ & Xylose residues & $17 \cdot 7$ \\
Crude fat & $57 \cdot 7$ & Glucose residues & $37 \cdot 3$ \\
Ash & $64 \cdot 5$ & Klason lignin & $14 \cdot 0$ \\
Soluble non-starch polysaccharides & $31 \cdot 3$ & Gross energy & $17 \cdot 2$ \\
$\quad$ Arabinose residues & $5 \cdot 5$ & & \\
Xylose residues & $8 \cdot 2$ & & \\
Glucose residues & $10 \cdot 8$ & & \\
\hline
\end{tabular}

Table 3. The dietary content $(\mathrm{g} / \mathrm{kg}$ ) of soluble pentosans after in vitro incubations for 20,60 and 180 min with different levels of a pentosanase preparation added to the broiler chicken diet based on rye and wheat*

\begin{tabular}{cccc}
\hline & \multicolumn{3}{c}{ Enzyme levels $(\mathrm{g} / \mathrm{kg})$} \\
\cline { 2 - 5 } $\begin{array}{c}\text { Incubation period } \\
(\text { min) }\end{array}$ & 0 & 0.44 & 4.40 \\
\hline 20 & 11.5 & 12.9 & 15.3 \\
60 & $13 \cdot 0$ & 14.4 & 14.7 \\
180 & 13.9 & 15.6 & 13.8 \\
Mean & 12.9 & 14.3 & 14.6 \\
SE & 0.7 & 0.8 & 0.5 \\
\hline
\end{tabular}

* For details of composition, see pp. 139 and 140 and Table 1.

\section{Growth}

Enzyme supplementation gave an increase $(P<0.001)$ in body-weight at both 15 and $27 \mathrm{~d}$ of age (Table 4). This effect was also significant $(P<0.001)$ during the period between 15 and $27 \mathrm{~d}$. A statistically significant linear relation for body-weights, at 15, 27 and 15$27 \mathrm{~d}$, was also found for groups receiving increasing levels of enzyme. Body-weight tended to increase at higher levels of enzyme addition.

\section{Feed intake}

There were significant effects on cumulative feed intake due to enzyme supplementation up to days 15 and 27 , and during the period from 15 to $27 \mathrm{~d}(P<0.01)$.

\section{Feed conversion efficiency}

Effects on feed conversion efficiency due to enzyme supplementation were observed up to both days 15 and $27(P<0 \cdot 001)$, but not during the period between 15 and $27 \mathrm{~d}$ of age $(P=0.37$; Table 4). Feed conversion efficiencies up to both days 15 and 27 and during the period between days 15 and 27 showed a significant $(P<0.05)$ trend towards improvement at higher levels of enzyme supplementation. 


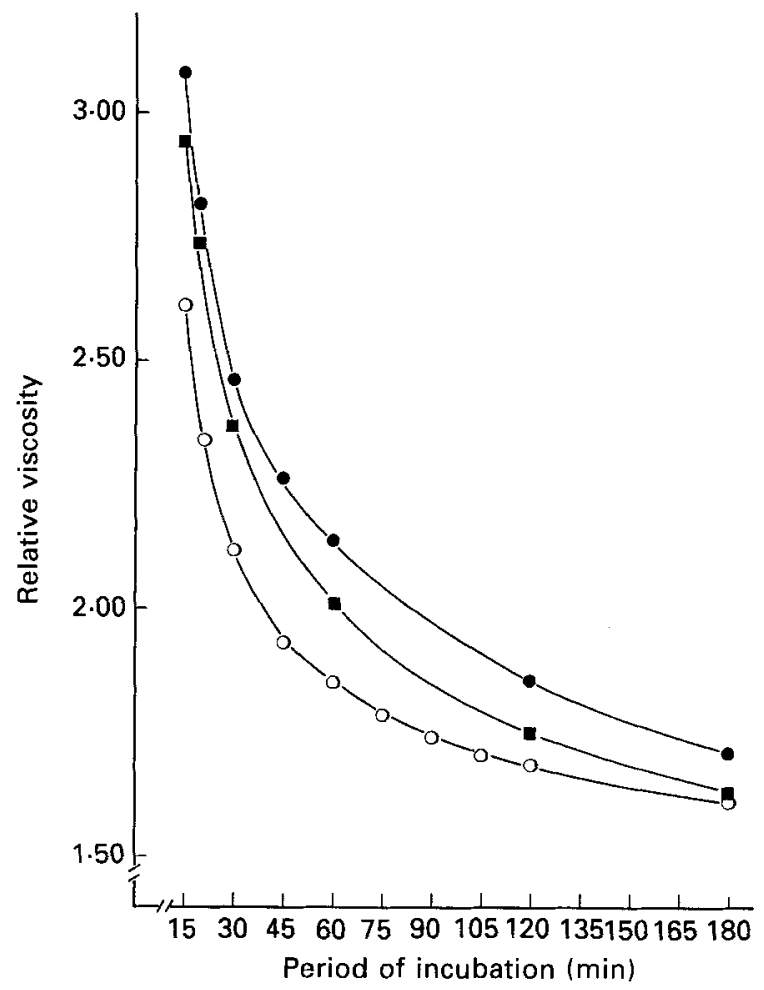

Fig. 1. Changes in relative viscosity (descent time of extracts/descent time of extraction medium) with incubation time for buffered $(0.1 \mathrm{~m}$-sodium acetate buffer, $\mathrm{pH} 5.0)$ extracts of the basal diet (for details of composition, see Table 1). (O), Without enzyme supplementation; ( $)$ ), with $0.44 \mathrm{~g}$ enzyme $/ \mathrm{kg}$; ( $\mathbf{0}$ ), with $4.4 \mathrm{~g}$ enzyme/ $\mathrm{kg}$ (for details of enzyme supplement, see pp. 139 and 140).

\section{Digestibility}

At day 20 the small intestine of animals fed at level 0 (unsupplemented) was on average $3 \%$ longer than for those fed on the enzyme-supplemented diets (Table 5). However, this was not statistically significant although a strong tendency $(P=0.08)$ was found. When relating intestinal length to body-weight, it was found that birds at level 0 (unsupplemented) had a longer $(P<0.001)$ gut compared with those supplemented with $0.11-0.88 \mathrm{~g} / \mathrm{kg}$ feed, and particularly in comparison with those supplemented with $0.88 \mathrm{~g} / \mathrm{kg}$ feed in which the gut was $700 \mathrm{~mm} / \mathrm{kg}$ shorter.

A strong tendency $(P=0.06)$ was found for an increased digesta dry matter content in the middle section of the small intestine as a result of enzyme supplementation (Table 5). There was also a significant $(P<0.05)$ increase in dry matter content at higher levels of enzyme supplementation. In the last section of the small intestine enzyme supplementation also resulted in a tendency $(P=0.10)$ towards an increased dry matter content. When looking at the frequency of sticky droppings, enzyme supplementation was found to improve $(P<0.01)$ conditions and at $0.88 \mathrm{~g} / \mathrm{kg}$ feed gave rise to a reduction to almost onethird of the frequency obtained at level 0 (unsupplemented).

With the exception of crude protein $(P<0.05)$, enzyme supplementation had no statistically significant effect on the digestibilities of dietary components in the middle section of the small intestine (Table 6), where a wide between-sample (group) variation was apparent. Although not statistically significant, numerically higher digestibilities were 
Table 4. The effect of giving diets with increasing levels of a pentosanase preparation* on chicken body-weight, feed intake and feed conversion efficiency at days 15 and 27

(Mean values)

\begin{tabular}{|c|c|c|c|c|c|c|c|c|c|}
\hline \multirow{2}{*}{$\begin{array}{c}\text { Production } \\
\text { variable }\end{array}$} & \multirow[b]{2}{*}{ Days } & \multicolumn{5}{|c|}{ Enzyme levels $\mathrm{g} / \mathrm{kg}$} & \multirow{2}{*}{$\begin{array}{l}\text { Pooled } \\
\text { standard } \\
\text { error } \\
(12 \mathrm{df})\end{array}$} & \multicolumn{2}{|c|}{$\begin{array}{c}\text { Statistical } \\
\text { significance of } \\
\text { difference: } P=\end{array}$} \\
\hline & & 0 & $0 \cdot 11$ & $0 \cdot 22$ & 0.44 & $0-88$ & & $\dagger$ & $\ddagger$ \\
\hline Body-wt (g) & $\begin{array}{l}15 \\
27\end{array}$ & $\begin{array}{l}282 \\
810\end{array}$ & $\begin{array}{l}347 \\
893\end{array}$ & $\begin{array}{l}350 \\
914\end{array}$ & $\begin{array}{l}364 \\
941\end{array}$ & $\begin{array}{l}373 \\
951\end{array}$ & $\begin{array}{l}5 \cdot 22 \\
9 \cdot 50\end{array}$ & $\begin{array}{l}0.001 \\
0.001\end{array}$ & $\begin{array}{l}0.002 \\
0.009\end{array}$ \\
\hline Wt gain (g) & $15-27$ & 524 & 545 & 564 & 576 & 577 & $7 \cdot 74$ & 0.001 & 0.020 \\
\hline Feed intake $(\mathrm{g})$ & $\begin{array}{l}1-15 \\
1-27 \\
15-27\end{array}$ & $\begin{array}{r}413 \\
1410 \\
997\end{array}$ & $\begin{array}{r}470 \\
1532 \\
1062\end{array}$ & $\begin{array}{r}464 \\
1519 \\
1055\end{array}$ & $\begin{array}{r}477 \\
1533 \\
1056\end{array}$ & $\begin{array}{r}482 \\
1531 \\
1049\end{array}$ & $\begin{array}{r}7 \cdot 71 \\
19 \cdot 04 \\
13 \cdot 66\end{array}$ & $\begin{array}{l}0.001 \\
0.001 \\
0.003\end{array}$ & $\begin{array}{l}0.148 \\
0.860 \\
0.547\end{array}$ \\
\hline $\begin{array}{l}\text { Feed conversion } \\
\text { efficiency ( } \mathrm{g} \text { feed/ } \\
\mathrm{g} \text { body-wt) }\end{array}$ & $\begin{array}{l}1-15 \\
1-27 \\
15-27\end{array}$ & $\begin{array}{l}1.46 \\
1.74 \\
1.89\end{array}$ & $\begin{array}{l}1 \cdot 36 \\
1 \cdot 72 \\
1.94\end{array}$ & $\begin{array}{l}1 \cdot 33 \\
1 \cdot 66 \\
1 \cdot 87\end{array}$ & $\begin{array}{l}1 \cdot 31 \\
1 \cdot 63 \\
1 \cdot 83\end{array}$ & $\begin{array}{l}1.29 \\
1.61 \\
1.82\end{array}$ & $\begin{array}{l}0.02 \\
0.02 \\
0.03\end{array}$ & $\begin{array}{l}0 \cdot 001 \\
0.001 \\
0.370\end{array}$ & $\begin{array}{l}0.042 \\
0.002 \\
0 \cdot 010\end{array}$ \\
\hline
\end{tabular}

* For details, see pp. 139 and 140, and for details of diet, see Table 1.

+0 v. $0 \cdot 11-0 \cdot 88 \mathrm{~g}$ enzyme $/ \mathrm{kg}$.

$\ddagger$ Linear relation for $0.11-0.88 \mathrm{~g}$ enzyme $/ \mathrm{kg}$.

Table 5. The effect of giving diets with increasing levels of a pentosanase preparation* on the length of the small intestine $(\mathrm{m})$, length of the small intestine in relation to body-weight $(\mathrm{m} / \mathrm{kg})$ and dry matter content $(\mathrm{g} / \mathrm{kg})$ in middle and last third of the small intestine of broiler chickens at day 20 and the frequency (\%) of sticky droppings (day 8 )

(Mean values)

\begin{tabular}{|c|c|c|c|c|c|c|c|c|}
\hline & \multicolumn{5}{|c|}{ Enzyme levels $(\mathrm{g} / \mathrm{kg})$} & \multirow{2}{*}{$\begin{array}{l}\text { Pooled } \\
\text { standard } \\
\text { error } \\
(12 \mathrm{df})\end{array}$} & \multicolumn{2}{|c|}{$\begin{array}{c}\text { Statistical } \\
\text { significance of } \\
\text { difference: } P=\end{array}$} \\
\hline & 0 & $0 \cdot 11$ & $0 \cdot 22$ & $0 \cdot 44$ & $0 \cdot 88$ & & $\dagger$ & $\ddagger$ \\
\hline \multicolumn{9}{|l|}{ Small intestine } \\
\hline Length (m) & $1 \cdot 32$ & $1 \cdot 27$ & $1 \cdot 32$ & $1 \cdot 24$ & $1 \cdot 27$ & 0.02 & 0.09 & $0 \cdot 36$ \\
\hline Relative length $(\mathrm{m} / \mathrm{kg})$ & $2 \cdot 90$ & $2 \cdot 30$ & $2 \cdot 39$ & $2 \cdot 22$ & $2 \cdot 20$ & 0.08 & 0.001 & 0.018 \\
\hline \multicolumn{9}{|l|}{ Middle section of small intestine } \\
\hline Dry matter content $(\mathrm{g} / \mathrm{kg})$ & 191 & 195 & 193 & 202 & 203 & $3 \cdot 1$ & $0 \cdot 06$ & 0.04 \\
\hline \multicolumn{9}{|l|}{ Last section of small intestine } \\
\hline \multicolumn{9}{|l|}{ Sticky droppings } \\
\hline Frequency at 8 days $(\%)$ & 31 & 22 & 17 & 13 & 11 & $4 \cdot 3$ & 0.009 & 0.11 \\
\hline
\end{tabular}

* For details, see pp. 139 and 140, and for details of diet, see Table 1.

+0 v. $0 \cdot 11-0 \cdot 88 \mathrm{~g}$ enzyme $/ \mathrm{kg}$.

† Linear relation for $0.11-0.88 \mathrm{~g}$ enzyme $/ \mathrm{kg}$.

observed for non-fibre components in the enzyme-supplemented diets, with digestibility increases of approximately $6 \%$ for organic matter, $10 \%$ for crude protein and $4 \%$ for starch. The digestibility of insoluble pentosans was generally higher with inclusion of the enzyme, while that of soluble pentosans generally was lower and negative at the three highest inclusion levels. 
ENZYME SUPPLEMENTATION OF A POULTRY DIET

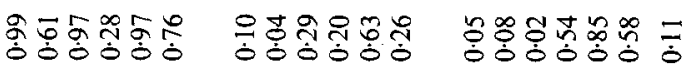

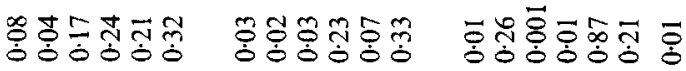

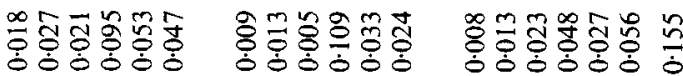

$\infty$
$\infty$
0
0
0

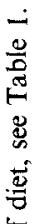

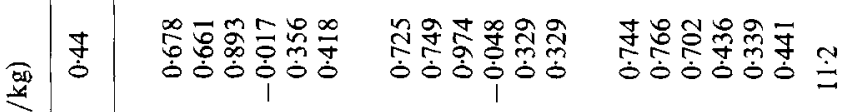

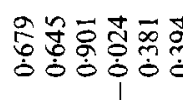

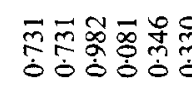

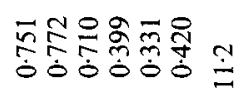

赵

(t)

$=$

ป

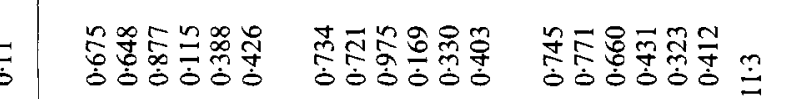

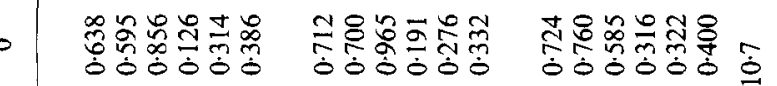


In the last third of the small intestine the between-sample variation was generally much smaller than in the preceding section. Enzyme inclusion increased $(P<0.05)$ the digestibilities of organic matter, crude protein, starch and insoluble pentosans by $3,6,1.5$ and $23 \%$ respectively, but had no effect on NSP degradation (Table 6). A general decrease in apparent digestibility of soluble pentosans with increasing enzyme levels, eventually leading to negative values, was again apparent.

Enzyme supplementation gave higher faecal digestibilities for organic matter and crude fat (by $4 \%$ and $21 \%$ respectively). Only traces of starch were detected in excreta samples. For the fibre constitutents, inclusion of the enzyme influenced $(P<0.05)$ the degradabilities only of soluble pentosans. Although not statistically significant, NSP and insoluble pentosan degradability increased with increasing enzyme inclusion, with a difference of almost $15 \%$ between inclusion at 0 and $0.88 \mathrm{~g} / \mathrm{kg}$ feed.

The degradability of total NSP residues was relatively constant at the three sites, on average $0.41,0.35$ and 0.43 for middle section, last section and excreta respectively. However, there was a tendency towards a higher degradability of pentosans in the faeces $(0.36)$ during days 21-24 than in the small intestine at day $20(0 \cdot 27$ and 0.25 in middle section and last section respectively).

The metabolizable energy content, corrected to zero $\mathrm{N}$ retention, was $10 \cdot 7 \mathrm{MJ} / \mathrm{kg}$ for the unsupplemented diet. Enzyme supplementation increased $(P<0.01)$ this value to an average of $11 \cdot 3 \mathrm{MJ} / \mathrm{kg}(+6 \%)$, with no significant difference between enzyme levels.

\section{DISCUSSION}

The increased dry matter content of digesta and the tendency for a shorter small intestine in chickens fed on enzyme-supplemented diets are similar to results obtained by Hesselman \& Åman (1986) when feeding barley-based diets with or without $\beta$-glucanase supplementation. The incidence of sticky droppings, which was high for chickens receiving the unsupplemented diet, is known to be associated with the feeding of rye to poultry (Halpin et al. 1936; Fernandez et al. 1973; Misir \& Marquardt, 1978; Marquardt et al. 1979; Jami et al. 1980). Increasing levels of enzyme supplementation consistently reduced the incidence of sticky droppings. Marked improvements in litter quality and a reduction in the frequency of sticky droppings have been observed in earlier experiments with the inclusion of a pentosanase preparation in rye-based diets (Pettersson \& $\AA$ man, 1988).

In the present experiment, low weight gain, depressed feed intake and poor feed conversion efficiency were obtained with the unsupplemented diet. Similar effects on performance when feeding rye-based diets to poultry have been demonstrated (Halpin $e t$ al. 1936; Moran et al. 1970). The positive response on performance which was obtained with increasing levels of the enzyme preparation agrees with other experiments regarding enzyme supplementation of rye-based diets (Day \& Thomas, 1980; Patel et al. 1980). In these earlier experiments, however, a pectinase (Irgazyme 100) was used. Since rye contains negligible amounts of pectic substances (Pettersson \& Åman, 1988) and the enzyme preparations were of technical grade, it is very likely that other enzymes in these preparations, e.g. pentosanases, were the active components.

It has been assumed that the poor performance of rye-fed chickens is caused by watersoluble pentosans (Antoniou \& Marquardt, 1981; Antoniou et al, 1981). These dietary fibre constituents are thought to increase the viscosity of the digesta in the gut, thus impeding absorption of nutrients, e.g. carbohydrates, amino acids, minerals, vitamins and fat (Marquardt et al. 1979; Ward \& Marquardt, 1983). Others have claimed that intact cell 
walls enclose the nutrients making them unavailable for digestion and absorption in the small intestine (Hesselman, 1983). Pentosans are present in the cereal walls both as soluble and insoluble components, and it is mainly high-molecular-weight soluble pentosans which are responsible for the viscosity of extracts or digesta. During digestion soluble pentosans may be degraded to more low-molecular-weight components by supplementary enzymes, mainly endo-enzymes, thus decreasing viscosity. These enzymes may also solubilize or degrade insoluble pentosans to lower molecular-weight components. If solubilized but not degraded these pentosans will add to the extract viscosity. In vitro incubations showed that the enzyme preparation used in the present trial could solubilize pentosans from feed components, and thereby actually increase the relative viscosity of a buffer extract from the enzyme-supplemented diet (Fig. 1). Degradation to low-molecular-weight components, not analysed as dietary fibre, was slow and could only be seen at the highest level ( $4.4 \mathrm{~g} / \mathrm{kg}$ diet) of enzyme inclusion. The negative apparent digestibilities observed for soluble pentosans in the small intestine indicate that the enzyme also solubilized pentosans in vivo. This increased solubilization of pentosans may have caused a disruption of intact cell walls, liberating enclosed nutrients, such as starch and protein, as has been shown by Hesselman $\&$ Åman $(1985,1986)$ in relation to $\beta$-glucanase-treated barley. Thus, results obtained indicate that viscosity in the present experiment may be of less consequence, and that the presence of intact cell walls which enclose nutrients perhaps is the more important of the two mechanisms suggested. The decrease in the incidence of sticky droppings on enzyme supplementation, as observed in the present and previous studies, is important for the health of the chicks, and may be due to a reduction in the water-binding capacity of dietary polysaccharides resulting from partial degradation by the supplementary enzymes.

The results from the quantitative digestibility trial showed a significant increase in the apparent digestion of soluble pentosans due to increasing levels of enzyme supplementation. Digestibility values for insoluble pentosans and total NSP, however, were not different from those found in the last two sections of the small intestine, indicating a very poor fermentation of insoluble fibre in caeca and colon. Björnhag \& Sperber (1977) have reported that fowl have a retrograde transport mechanism in the colon which returns soluble matter and fine particles, but not larger feed particles, to the caeca. Thus, the greater digestion of soluble fibre but little effect on the insoluble fraction, as observed in the present study, could be expected. The degradation of fibre before the middle of the small intestine suggests that bacteria or endogenous feed enzymes in the crop and gizzard are primarily responsible for fibre degradation in the chick.

The digestibility values for fat and the improvements obtained for fat retention in chickens fed on diets supplemented with $0.22-0.88 \mathrm{~g}$ enzyme $/ \mathrm{kg}$ in comparison with those fed on the unsupplemented diet, were similar to values given by Marquardt et al. (1987) for rye-based chicken diets given without and with a fungal enzyme preparation.

The present study has again illustrated that the increased body-weights observed in chicks on enzyme-supplemented diets $(+27$ and $+14 \%$ at days 15 and 27 respectively) cannot be explained from increased organic matter digestibility $(+4 \%)$ or metabolizable energy content $(+6 \%)$. It has established that supplementation with an appropriate enzyme can partially degrade feed endosperm cell walls, giving a more rapid and extensive digestion of starch, protein and other nutrients in the small intestine, and consequently a higher feed intake and better feed conversion efficiency.

Enzyme supplementation of commercial diets is now a fairly common practice within Scandinavia, particularly for barley-containing diets, giving both healthier chicks and better production results. The development of inexpensive enzyme preparations capable of withstanding processing conditions and degrading endosperm cell walls under the 
conditions encountered in the chick foregut will undoubtedly increase this practice. However, it is at present not possible to predict from chemical analysis of the diet the extent of improvement, if any, to be expected with enzyme supplementation.

The staff at the Division of Feed Chemistry is gratefully acknowledged for excellent technical assistance.

\section{REFERENCES}

Åman, P. \& Hesselman, K. (1984). Analysis of starch and other main constituents of cereal grains. Swedish Journal of Agricultural Research 14, 135-139.

Anon. (1971). Determination of crude oils and fats. Official Journal of the European Communities L297, 995-997.

Antoniou, T. \& Marquardt, R. R. (1981). Influence of rye pentosans on the growth of chicks. Poultry Science 60, 1898-1904.

Antoniou, T., Marquardt, R. R. \& Cansfield, P. E. (1981). Isolation, partial characterization and antinutritional activity of a factor (pentosans) in rye grain. Journal of Agricultural and Food Chemistry 29, 1240-1247.

Association of Official Analytical Chemists (1984). Official Methods of Analysis, 14th ed. Washington, DC: Association of Official Analytical Chemists.

Björnhag, G. \& Sperber, I. (1977). Transport of various food components through the digestive tract of turkeys, geese and guinea fowl. Swedish Journal of Agricultural Research 7, 57-66.

Boros, D., Rakowska, M., Raczyńska-Bojanowska, K. \& Kozacyński, K. (1985). The response of Japanese quails and chicks to the water-soluble antinutritive compounds from rye grain. Nutrition Reports International 32, $827-836$.

Burnett, G. S. (1966). Studies on viscosity as the probable factor involved in the improvement of certain barleys for chickens by enzyme supplementation. British Poultry Science 7, 55-75.

Day, R. M. \& Thomas, O. P. (1980). Growth depression of chicks fed a crude rye extract containing pectic substances. Poultry Science 59, 2754-2759.

Eriksson, S. (1955). Digestibility and metabolizable energy of poultry rations at different levels of nutrition. Acta Agriculturae Scandinavica 5, 201-204.

Fernandez, R., Lucas, E. \& McGinnis, J. (1973). Fractionation of a chick growth depressing factor from rye. Poultry Science 52, 2252-2259.

Fincher, G. B. (1975). Morphology and chemical composition of barley endosperm ceil walls. Journal of the Institute of Brewing 81, 116-122.

Forrest, I. S. \& Wainwright, T. (1977). The mode of binding of $\beta$-glucans and pentosans in barley endosperm cell walls. Journal of the Institute of Brewing 83, 279-286.

Fry, R. E., Allred, J. B., Jensen, L. S. \& McGinnis, J. (1958). Influence of enzyme supplementation and water treatment on the nutritional value of different grains for poults. Poultry Science 37, 372-375.

Halpin, J. G., Holmes, C. E. \& Hart, E. B. (1936). Rye as a feed for poultry. Poultry Science 15, 3-8.

Hartfiel, W. (1973). Richtlinien zur Durchführung von Bilanzversuchen mit Hühnern. Archiv für Geflügelkunde $2,49-57$.

Henry, R. J. (1985). A comparison of the nonstarch carbohydrates in cereal grains. Journal of the Science of Food and Agriculture 36, 1243-1253.

Hesselman, K. (1983) Effects of $\beta$-glucanase supplementation to barley based diets for broiler chickens. $\mathrm{PhD}$ Thesis, Swedish University of Agricultural Sciences.

Hesselman, K. \& Åman, P. (1985). A note on microscopy studies on water- and $\beta$-glucanase-treated barley. Swedish Journal of Agricultural Research 15, 139-143.

Hesselman, K. \& Aman, P. (1986). The effect of $\beta$-glucanase on the utilization of starch and nitrogen by broiler chickens fed on barley of low or high viscosity. Animal Feed Science and Technology 15, 83-93.

Jami, M. S., Pubols, M. H. \& McGinnis, J. (1980). Effect of gamma irradiation on the physicochemical properties of rye. Poultry Science 59, 253-257.

Jensen, L. S., Fry, R. E., Allred, J. B. \& McGinnis, J. (1957). Improvement in the nutritional value of barley for chicks by enzyme supplementation. Poultry Science 36, 919-921.

Larsson, K. \& Bengtsson, S. (1983). Metodbeskrivning Nr. 22 (in Swedish), pp. 1-9. Uppsala: Statens lantbrukskemiska laboratorium.

Mares, D. J. \& Stone, B. A. (1973). Studies on wheat endosperm. I. Chemical composition and ultrastructure of the cell walls. Australian Journal of Biological Science 26, 793-812.

Marquardt, R. R. (1983). A simple spectrophotometric method for the direct determination of uric acid in avian excreta. Poultry Science 62, 2106-2108.

Marquardt, R. R., Fengler, A. I. \& Pawlik, J. (1987). Improvement of the nutritional value of cereal grains through the use of crude enzymes of microbial origin. Third Annual Biotechnology in the Feed Industry Symposium, pp. 1-14. Lexington, Winnipeg: University of Manitoba. 
Marquardt, R. R., Ward, A. T. \& Misir, R. (1979). The retention of nutrients by chicks fed rye diets supplemented with amino acids and penicillin supplementation. Poultry Science 58, 631-640.

Misir, R. \& Marquardt, R. R. (1978). Factors affecting rye (Secale cereale L.) utilization in growing chicks. I. The influence of rye level, ergot and penicillin supplementation. Canadian Journal of Animal Science 58, 691-701.

Moran, E. T. Jr, Lall, S. P. \& Summers, J. D. (1970). Altering the proportion of rye to maize in the grain fraction of practical broiler rations: effect on live performance, litter moisture, dressing yield and carcass quality. British Poultry Science 11, 147-152.

Patel, M. B., Jami, M. S. \& McGinnis, J. (1980). Effect of gamma irradiation, penicillin, and/or pectic enzyme on chick growth depression and fecal stickiness caused by rye, citrus pectin and guar gum. Poultry Science 59, 2105-2110.

Pettersson, D. \& Åman, P. (1988). Effects of enzyme supplementation of diets based on wheat, rye or triticale on their productive value for broiler chickens. Animal Feed Science and Technology 20, 313-324.

Pettersson, D., Hesselman, K. \& Åman, P. (1987). Nutritional value for chickens of dried distillers-spent-grain from barley and dehulled barley. Animal Feed Science and Technology 17, 145-156.

SAS Institute Inc. (1985). SAS User's Guide: Statistics, pp. 1-956. Cary, North Carolina: SAS Institute Inc.

Scholtyssek, Von S. \& Knorr, R. (1987). Die Wirkung eines cellulolytischen Enzympräparates bei Verfütterung von Triticale- und Roggenrationen an Broiler. Archiv für Geflügelkunde 51, 10-15.

Theander, O. \& Åman, P. (1979). Studies on dietary fibres. 1. Analysis and chemical characterization of watersoluble and water-insoluble dietary fibres. Swedish Journal of Agricultural Research 9, 97-106.

Theander, O. \& Westerlund, E. (1986). Studies on dietary fibers. III. Improved procedures for analysis of dietary fibers. Journal of Agricultural and Food Chemistry 34, 330-336.

Ward, A. T. \& Marquardt, R. R. (1983). The effect of saturation, chain length of pure triglycerides, and age of bird on the utilization of rye diets. Poultry Science 62, 1054-1062.

White, W. B., Bird, H. R., Sunde, M. L., Prentice, N., Burger, W. C. \& Marlett, J. A. (1981). The viscosity interaction of barley beta-glucan with Trichoderma viride cellulase in the chick intestine. Poultry Science 60, 1043-1048.

Williams, C. H., David, D. J. \& Iismaa, O. (1962). The determination of chromic oxide in faeces samples by atomic absorption spectrophotometry. Journal of Agricultural Science 59, 381-385. 